\title{
Maintenance of species dominance through pulse disturbances to a sessile marine invertebrate assemblage in Port Shelter, Hong Kong
}

\author{
Emma L. Johnston ${ }^{1, *}$, Michael J. Keough ${ }^{1}$, Pei-Yuan Qian ${ }^{2}$ \\ ${ }^{1}$ Department of Zoology, University of Melbourne, Victoria 3010, Australia \\ ${ }^{2}$ Department of Biology, Hong Kong University of Science and Technology, Clear Water Bay, Kowloon, Hong Kong, SAR
}

\begin{abstract}
Pollution events can be considered as disturbances to an ecosystem and have the potential to be an important structuring force within assemblages of plants and animals. Our understanding of pollution impacts will benefit from the investigation of important aspects of these disturbances such as their timing and frequency. We investigated the effect of pulse copper pollution events on the development of hard-substrate invertebrate assemblages in Port Shelter, Hong Kong. Using a field dosing technique, we created single or repeated copper pollution events of less than $100 \mathrm{\mu g}^{-1}$ close to settlement plates. In short-term experiments, pulses were delivered in either the first or the second week of substrate immersion. For longer term experiments, pulses were delivered every 2, 4, 8 or 16 wk for the duration of the 16 wk experiments and the assemblages allowed to develop under these dosing regimes. Pulse pollution events had a dramatic effect on densities of the dominant colonizer and space occupier in short-term experiments, Hydroides elegans. The impact was observed as a change in the size structure of the population with large organisms eliminated close to copper sources while new recruits were increased in densities in the same area. Reductions in densities of bryozoans and barnacles were also observed, while a feather hydroid doubled in densities on plates exposed to copper pulses. Young assemblages recovered rapidly from the impact of a copper pulse and reduced impacts were observed from a copper pulse in Week 1 of the experiments compared to exposure in Week 2. In longer-term experiments, copper pulses also dramatically altered assemblages predominantly through a direct negative effect on the densities of large competitively superior colonial and solitary ascidians. In the absence of a regular pollution event, colonial and solitary ascidians and sponges were able to establish, grow-over and/or push out the smaller, more brittle $H$. elegans. These good competitors were unable to establish and grow to any great size on plates exposed to copper pulses every 2 or $4 \mathrm{wk}$ and under the influence of repeated pulse copper exposures $H$. elegans maintained its initial dominance. Assemblages exposed every 8 or 16 wk were not significantly different from undosed controls. The results provide information on the type and magnitude of sessile invertebrate responses to transient pollution events as well as an assessment of the time expected to 'assemblage recovery' from single or repeated pulse disturbances. This is discussed in relation to the results of identical experiments conducted in temperate climates.
\end{abstract}

KEY WORDS: Copper · Pulse disturbance $\cdot$ Frequency $\cdot$ Indirect effects $\cdot$ Field experiment $\cdot$ Sessile invertebrates · Recruitment - Disturbance 


\section{INTRODUCTION}

Coastal marine and estuarine environments have long been used as disposal areas for industrial, metabolic and mining wastes. They are also subject to transient toxicant releases that may occur in the form of spills or runoff from agricultural and urban areas, as well as deliberate release in the form of antifouling biocides. Many of these events are episodic, recurring at a range of intervals. Their effect on nearshore biota is likely to depend not only on the intensity of any single event but also on the frequency, i.e. the intervals between events. Predicting impacts of such episodic disturbances is likely to prove difficult.

For a combination of historical, legislative and practical reasons, laboratory studies of the impacts of particular toxicants on single species continue to be the most common way of generating predictions of toxicant impacts or assessing the toxicity of particular compounds (Calow 1994). They have been used partly because there are no appropriate field ecological techniques, and partly because they provide highly repeatable assays, while field assessments include the considerable variability associated with natural environments. While laboratory approaches have provided much useful information, they have been criticized for their simplicity. In particular, they involve single, usually intensive, exposure to toxicants, and it is not clear how data from these approaches can be used to predict the effects of recurrent disturbances (Schratzberger \& Warwick 1998). Furthermore, most toxicants are modified by the surrounding water chemistry, which can be highly variable in natural waters (Levine 1989). A third limitation of most of the widely used laboratory approaches is that they assess a single species sensitivity when impacts on particular organisms are likely to be influenced by the organisms' interactions with neighbors (DeAngelis 1996). Such limitations provide a strong argument for field tests of the effects of transient pollution events.

Adult sessile marine organisms have no physical means to escape water-borne exposure to toxicants, which makes them important subjects for studies of the effects of contaminants on marine organisms. Field studies have recognized the importance of disturbances such as wave, log, or hurricane action in structuring marine invertebrate hard-substrate assemblages (Dayton 1971, Connell 1978, Sousa 1980). Both predation and abiotic disturbances create open space (a primary limiting resource in these assemblages) and there has been considerable interest in the effects of interactions between space-creating disturbances and concurrent assemblage processes such as competition and recruitment (Connell 1978, Paine \& Levin 1981, Gaines \& Roughgarden 1985, Menge \& Sutherland 1987, Hughes \& Connell 1999).
Anthropogenic disturbances from chemical inputs have the potential to cause not only the direct mortality of resident or recruiting organisms, but through such direct mortality, to indirectly alter the structure of communities (Keough \& Quinn 1998). Should the toxicant cause selective mortality of taxa in the field, more dramatic structural changes may ensue. Conventional tests conducted on a single species or population lack the ability to predict the indirect effects of toxicants on organisms that are mediated through a limiting resource such as space (Kimball \& Levin 1985, Luoma 1995, DeAngelis 1996).

Along with other heavy metals, copper is a common toxicant input into coastal waters and estuaries worldwide, and there is a growing body of evidence that relates the toxicity of a metal to its concentration in hydrated ion form (Campbell 1995). The nature of the chemistry of copper (as a chelating ion) and its potential sources of input into the marine environment (urban runoff, industry discharge, spills, mining and metabolic wastes) combine to suggest that water-born exposures to high concentrations of the toxic form of the metal are likely to be brief (Hall et al. 1998). Although an essential trace element for growth and metabolism of marine invertebrates, conventional laboratory studies have identified copper as a highly toxic element at higher concentrations, interfering with metabolic pathways and binding to enzymes and gill structures (Hall et al. 1998). In general, larvae are more sensitive than adults to toxicant exposure (Bryan 1971, Pechenik 1987) and the biological effects of copper on marine and estuarine organisms have been extensively reviewed by Lewis \& Cave (1982).

We describe a complement of short- and longer-term manipulative field experiments in which we examine the impacts of varied timing and frequencies of transient copper pulses on the development of sessile marine invertebrate assemblages in Port Shelter, Hong Kong. To investigate the effects of the timing of pulse pollution events, short-term ( $2 \mathrm{wk}$ ) experiments were conducted in which copper pulses were delivered in either the first or the second week of substrate immersion. A longer term experiment (16 wk) was used to examine the impact of different frequencies of pulse pollution events. Pulses were delivered every 2, 4, 8 or $16 \mathrm{wk}$ for the duration of the experiment and the assemblages were allowed to develop under these dosing regimes. The results provide information on the type and magnitude of sessile invertebrate responses to transient pollution events as well as an assessment of the time expected to 'assemblage recovery' from single or repeated pulse disturbances. Water analyses were conducted to characterize the temporal and spatial nature of the copper pulses being created by our field dosing system. 


\section{MATERIALS AND METHODS}

Field experiments. Site: Experiments were suspended from a floating pier at the perimeter of V. Whale Ltd. fish farm in Port Shelter, Hong Kong (22 $10^{\prime}$ N, $\left.114^{\circ} 16^{\prime} \mathrm{W}\right)$. Some of the more common sessile invertebrates that settle on hard substrates at the Pier are well-studied, including the serpulid Hydroides elegans (Gosselin \& Qian 1997, Qian \& Pechenik 1998, Qiu \& Qian 1998), the barnacle Balanus amphitrite (Gosselin \& Qian 1997, Qiu \& Qian 1997b, Qiu et al. 1997), and the bryozoan Bugula neritina (Bryan et al. 1998). Assemblages often include these species along with other polychaetes, barnacles and bryozoans, and a range of sponges, hydroids, and ascidians. Hong Kong's climate is subtropical and the mean summer surface water temperature maximum is $27^{\circ} \mathrm{C}$ (Morton 1987). Surface water salinities may vary, decreasing in summer due to the influx of freshwater from summer rains (from $>33$ to $<20 \%$ in the top $1 \mathrm{~m}$, pers. obs.). All of the dosing experiments described here were conducted during the spring and early summer of 1998 at a depth of $>3.5 \mathrm{~m}$, and water temperatures and salinity measures were taken during water sampling experiments.

Toxicant dosing: In all experiments, AR grade $\mathrm{CuSO}_{4}$ (copper II sulfate anhydrous) was used as the toxicant. Plaster blocks were made according to Johnston \& Webb (2000). To describe the process briefly, $3.2 \mathrm{~g}$ of $\mathrm{CuSO}_{4}$ was completely dissolved in $13 \mathrm{~g}$ of deionized water and mixed with $15 \mathrm{~g}$ of dental plaster. The plaster was poured into a hemispherical plastic mold, $4 \mathrm{~cm}$ in diameter. A stainless steel bolt $(35 \times 5$ $\mathrm{mm}$ ) was placed head down into the plaster and the block was allowed to set at $30^{\circ} \mathrm{C}$ until a constant dry weight was recorded (Day 4 to 5). The same process was used to manufacture control blocks except for the addition of the $\mathrm{CuSO}_{4}$.

Replicate settlement plates ( 4 to 8 depending on the experiment) were assigned to each treatment. A plate consisted of an $11 \times 11 \times 1 \mathrm{~cm}$ black Perspex sheet roughened by sanding on the settlement surface. Copper-impregnated plaster blocks were attached to the center of settlement plates by their stainless steel bolts, which served also to secure the plate to a larger $60 \times 60 \mathrm{~cm}$ gray PVC backing plate. Backing plates allowed the stable submersion of several settlement plates. Eight small settlement plates were attached to every backing plate, with the distance between the edges of neighboring plates being no less than $10 \mathrm{~cm}$. To avoid possible bias by differential recruitment on to areas of backing plates, positions were divided into 3 categories: corner, center or edge. Treatments were spread equally across each category. Settlement plates were attached to the underside of backing plates to minimize available light and sedimentation. For an illustration of the plaster block and plates experimental set-up see Johnston \& Keough (in press). A weight was attached below the backing plate to provide stability and all plates were suspended at a depth of $3.5 \mathrm{~m}$.

Short-term experiments: Two 2 wk experiments were conducted in May and June of 1998. For each 2 wk experiment, there were 3 treatments: an undosed control, a copper dose in Week 1, and a copper dose in Week 2. At the conclusion of each experiment, settlement plates were transported in seawater to the laboratory and placed in a continuous flow seawater system until they were examined (within $48 \mathrm{~h}$ ). Plates were examined under a binocular dissecting microscope and the position of recruits within each $1 \mathrm{~cm}^{2}$ of two $10 \mathrm{~cm}$ transects bisecting the plate were noted (this excluded a $0.5 \mathrm{~cm}$ settlement plate 'edge' area). Many taxa were counted in several size classes. If size classes responded in the same way to treatments, or, if there were insufficient recruits within a size class to warrant analysis, then size class data were pooled. For new settlers of solitary ascidians $(<0.5 \mathrm{~cm})$ it was not possible to consistently discriminate between species so they were pooled and analyzed as a group (i.e. 'newly settled solitary ascidians').

Analysis of short-term experiments. Analyses were run in 2 distinct ways depending on the density of recruits. For organisms that recruited in densities $>0.5 \mathrm{~cm}^{-2}$, the density of recruits was analyzed using a repeated measures analysis, with plates as the 'subjects' and recruitment at different distances being the repeated measurements. This approach is equivalent to calculating the linear trend in density with distance for each plate and comparing the slopes between treatments, then the quadratic trend, etc. The between-subjects factor was copper treatment; the within-subjects factor was distance from the copper source. The assumption of sphericity was checked using the Huyn Feldt $(H-F)$ epsilon value, and where transforming greatly improved this value the $\log _{10}(x+1)$ values are presented. Since there were significant differences in almost every repeated measures test, no power values were calculated for these analyses. For organisms that recruited in densities $<0.5 \mathrm{~cm}^{-2}$ in all treatments an analysis of variance was conducted on the mean density across the whole plate for each taxonomic group with copper treatment as the categorical factor. Residual plots were examined for homogeneity of variance and analyses were conducted on the raw data in all cases. Where there was a non-significant result in a test a power analysis was conducted using PiFace ${ }^{1}$. The power of the experiments to detect a $50 \%$ difference of a copper dose in Week 2 from control was calculated, as effects of this

\footnotetext{
${ }^{1}$ Lenth R (1997) Java applets for power and sample size. University of Iowa, lowa City, IA. Available at: www.stat.uiowa.edu/ rlenth/Power
} 
magnitude have been reported in previous copper pulse 2 wk experiments (Johnston \& Keough 2000).

Longer-term experiment: We ran a single 16 wk experiment beginning in early May in which all plates received either a copper-impregnated or control plaster block at the beginning of each fortnight. There were 5 treatments that comprised of an undosed control, a copper pulse every $2,4,8$ or $16 \mathrm{wk}$ (hereafter referred to as Control, $2 \mathrm{wk}, 4 \mathrm{wk}, 8 \mathrm{wk}$ and $16 \mathrm{wk}$ respectively). The first copper pulse of every treatment was attached at the end of $1 \mathrm{wk}$ of plate immersion on site, which allowed for the development of a biofilm. At the end of the experiment, $35 \mathrm{~mm}$ slide photographs were taken of the plates and examined by projection onto a white sheet. The position of recruits within each $1 \mathrm{~cm}^{2}$ of two $10 \mathrm{~cm}$ transects that bisected the plate were noted (this excluded a $0.5 \mathrm{~cm}$ settlement plate 'edge' area).

Analysis of longer-term experiment: The density of recruits was analyzed using a repeated measures analysis, with plates as the 'subjects' and recruitment at different distances being the repeated measurements. The between-subjects factor was copper treatment; the within-subjects factor was distance from the copper source. The assumption of sphericity was checked using the Huyn Feldt $(H-F)$ epsilon value, and where transforming greatly improved this value the $\log _{10}(x+1)$ values are presented. Tukey's tests were conducted on the main effect to determine which of the 5 treatments differed. Since there were significant differences in every repeated measures test, no power values were calculated for these analyses.

In situ copper pulse measurement: Two experiments were conducted to measure the concentration of copper in the water created by the plaster block dosing technique. The first experiment measured copper levels directly in front of copper and control plaster blocks 24, 72 and $120 \mathrm{~h}$ after the plates were submerged. At each time, SCUBA divers used $60 \mathrm{ml}$ plastic syringes to take water samples $2 \mathrm{~cm}$ directly in front of 4 replicate plaster and 4 replicate copper blocks. The second experiment measured copper concentrations at different distances from 4 replicate copper blocks, $24 \mathrm{~h}$ after the plates were submerged. In this study, water samples were taken through holes drilled in the backing plate at 1,6 and $26 \mathrm{~cm}$. The samples pooled $15 \mathrm{ml}$ from each of 4 directions at each distance around each plaster block (i.e. North, South, East and West). Thus, they constituted the average concentration at a particular distance from the copper source regardless of variation caused by directional currents. In both experiments, all glass and plastic ware were soaked in $10 \% \mathrm{HNO}_{3}(\mathrm{v} / \mathrm{v})$ for at least $48 \mathrm{~h}$ and rinsed several times in deionized water prior to use. Water samples were vacuum filtered immediately on collection through a 0.45 micron filter and acidified to the equivalent of $1.5 \mathrm{ml} \mathrm{l}^{-1}$ con- centrated $\mathrm{HNO}_{3}$ and refrigerated at $4{ }^{\circ} \mathrm{C}$ to prevent sorption to the plastic container walls. Three subsamples of $5 \mathrm{ml}$ were then taken on 3 occasions and digested using $5 \mathrm{ml}$ of concentrated $\mathrm{HNO}_{3}$ and $1.5 \mathrm{~h}$ in a heater at $150^{\circ} \mathrm{C}$. The subsample was then diluted to $50 \mathrm{ml}$ with deionized $\mathrm{H}_{2} \mathrm{O}$ and analyzed by graphite furnace aspiration on an atomic absorption spectrophotometer. The average of the 3 subsample aspirations is used as the single replicate value. Trip blanks and filtered blanks were analyzed with each batch.

\section{RESULTS}

\section{Field experiments}

\section{Short-term experiments}

Recruitment in both short-term experiments was dominated by the serpulid polychaete Hydroides elegans. Within the $2 \mathrm{wk}$ that the plates were submerged $H$. elegans settled and grew to cover more than $50 \%$ of primary space on control plates. In the first experiment, they occurred in densities of $60 \mathrm{~cm}^{-2}$ dropping in the second experiment to $30 \mathrm{~cm}^{-2}$. Other organisms settled in-between $H$. elegans recruits, including the barnacle Balanus amphitrite, the encrusting bryozoan Schizoporella unicornis, hydroids, colonial and solitary ascidians, amphipods and bivalves.

Recruitment with distance from the copper sourcerepeated measures analysis

For organisms that recruited in densities $>0.5 \mathrm{~cm}^{-2}$ in at least 1 treatment, repeated measures analyses were used to test for the effects of copper with distance from the source. Results from the repeated measures analyses of both short-term experiments are summarized in Table 1. Hydroides elegans recruits were counted in 3 size classes: large (width of tube opening $>500 \mu \mathrm{m}$ ) medium (width of tube opening $<500 \mu \mathrm{m}$ and $>200 \mu \mathrm{m}$ ) and newly settled (width of tube opening $<200 \mu \mathrm{m})$. The width of tube opening was used as a guide to size since high densities precluded the possibility of measuring tube length. In both short-term experiments, a copper pulse in Week 2 greatly reduced the density of large $H$. elegans, and this impact increased with increasing proximity to the copper source. Densities were halved at the furthest distance from the source and reduced to virtually zero immediately next to the source (Figs $1 \& 2$ ). A copper pulse in Week 1 reduced the densities of large $H$. elegans in both experiments but did not affect the distribution across the plate (Figs $1 \& 2$ ). Recruitment of medium 
Table 1. Analysis of effect of copper pulses on density of recruits in 2 wk Expts 1 and 2. Table shows effects of copper on recruitment for the whole plate (Whole plate, $\mathrm{df}=2,12)$, and on recruitment patterns with distance from the source $($ Within plate, $\mathrm{df}=$ $3,6,36)$. Mean square values are provided to allow reconstruction of the full repeated measures analysis table. Bold: statistically significant at $\mathrm{p}<0.05$ or less

\begin{tabular}{|c|c|c|c|c|c|c|}
\hline \multirow[t]{2}{*}{ Taxon } & & & \multicolumn{2}{|c|}{ Expt 1} & \multicolumn{2}{|c|}{ Expt 2} \\
\hline & & & MS & $\mathrm{p}$ & MS & $\mathrm{p}$ \\
\hline \multirow[t]{5}{*}{ Large Hydroides elegans } & Whole plate & Treatment & 391.866 & $<0.001$ & 452.115 & $<0.001$ \\
\hline & & Error & 3.061 & & 4.148 & \\
\hline & Within plate & Distance & 51.268 & $<0.001$ & 24.412 & $<0.001$ \\
\hline & & Distance $\times$ Treatment & 8.903 & 0.001 & 13.053 & $<0.001$ \\
\hline & & Error & 1.807 & & 1.726 & \\
\hline \multirow{5}{*}{ Medium $H$. elegans } & Whole plate & Treatment & 1557.529 & $<0.001$ & 33.579 & $<0.001$ \\
\hline & & Error & 50.416 & & 1.629 & \\
\hline & Within plate & Distance & 5.886 & 0.494 & 3.15 & 0.015 \\
\hline & & Distance $\times$ Treatment & 45.507 & $<0.001$ & 1.317 & 0.167 \\
\hline & & Error & 7.225 & & 0.833 & \\
\hline \multirow[t]{5}{*}{ Small $H$. elegans } & Whole plate & Treatment & 1462.128 & 0.266 & 1045.711 & 0.038 \\
\hline & & Error & 988.013 & & 271.581 & \\
\hline & Within plate & Distance & 131.687 & 0.013 & 30.247 & 0.043 \\
\hline & & Distance $\times$ Treatment & 124.718 & 0.004 & 21.512 & 0.072 \\
\hline & & Error & 31.876 & & 10.488 & \\
\hline \multirow[t]{5}{*}{ All H. elegans } & Whole plate & Treatment & 337.079 & 0.736 & 517.971 & 0.167 \\
\hline & & Error & 1073.178 & & 265.775 & \\
\hline & Within plate & Distance & 92.179 & 0.207 & 131.155 & $<0.001$ \\
\hline & & Distance $\times$ Treatment & 73.154 & 0.297 & 28.293 & 0.033 \\
\hline & & Error & 57.755 & & 11.434 & \\
\hline \multirow[t]{5}{*}{ Newly settled ascidians } & Whole plate & Treatment & 2.760 & 0.244 & & \\
\hline & & Error & 1.736 & & & \\
\hline & Within plate & Distance & 0.972 & 0.031 & & \\
\hline & & Distance $\times$ Treatment & 0.352 & 0.328 & & \\
\hline & & Error & 0.293 & & & \\
\hline Feather hydroid & Whole plate & Treatment & 0.392 & 0.047 & 234.192 & 0.176 \\
\hline \multirow[t]{4}{*}{$\log _{10}+1$ in Expt 1} & & Error & 0.098 & & 123.897 & \\
\hline & Within plate & Distance & 0.007 & 0.780 & 37.674 & 0.051 \\
\hline & & Distance $\times$ Treatment & 0.005 & 0.954 & 44.012 & 0.008 \\
\hline & & Error & 0.018 & & 13.776 & \\
\hline \multirow[t]{5}{*}{ Hydroid sp. 1} & Whole plate & Treatment & & & 1.453 & 0.025 \\
\hline & & Error & & & 0.331 & \\
\hline & Within plate & Distance & & & 0.107 & 0.009 \\
\hline & & Distance $\times$ Treatment & & & 0.045 & 0.118 \\
\hline & & Error & & & 0.025 & \\
\hline \multirow[t]{5}{*}{ Large Schizoporella sp. } & Whole plate & Treatment & 3.514 & 0.007 & 1.683 & $<0.001$ \\
\hline & & Error & 0.456 & & 0.080 & \\
\hline & Within plate & Distance & 1.559 & $<0.001$ & 0.070 & 0.165 \\
\hline & & Distance $\times$ Treatment & 0.330 & 0.058 & 0.051 & 0.281 \\
\hline & & Error & 0.145 & & 0.040 & \\
\hline \multirow[t]{5}{*}{ Small Schizoporella sp. } & Whole plate & Treatment & 1.774 & 0.038 & 0.119 & 0.439 \\
\hline & & Error & 0.409 & & 0.139 & \\
\hline & Within plate & Distance & 0.586 & 0.045 & 0.512 & 0.004 \\
\hline & & Distance $\times$ Treatment & 0.332 & 0.155 & 0.275 & 0.022 \\
\hline & & Error & 0.198 & & 0.102 & \\
\hline \multirow[t]{5}{*}{ Dead Schizoporella sp. } & Whole plate & Treatment & 3.164 & $<0.001$ & 1.196 & 0.001 \\
\hline & & Error & 0.100 & & 0.111 & \\
\hline & Within plate & Distance & 0.510 & 0.031 & 0.114 & 0.233 \\
\hline & & Distance $\times$ Treatment & 0.466 & 0.017 & 0.045 & 0.743 \\
\hline & & Error & 0.154 & & 0.078 & \\
\hline
\end{tabular}

sized $H$. elegans showed similar patterns to the large size class in the first experiment, although they recruited in higher densities and there was little difference between the Control and Week 1 treatments (Fig. 1). Recruitment of medium sized H. elegans dropped in the second experiment and a copper pulse in Week 2 increased their densities although there was no difference in the distributions across the plate (Fig. 2). A copper pulse in Week 2 increased the densities of small $H$. elegans by $100 \%$ close to the source in 



Copper pulse in Week 2
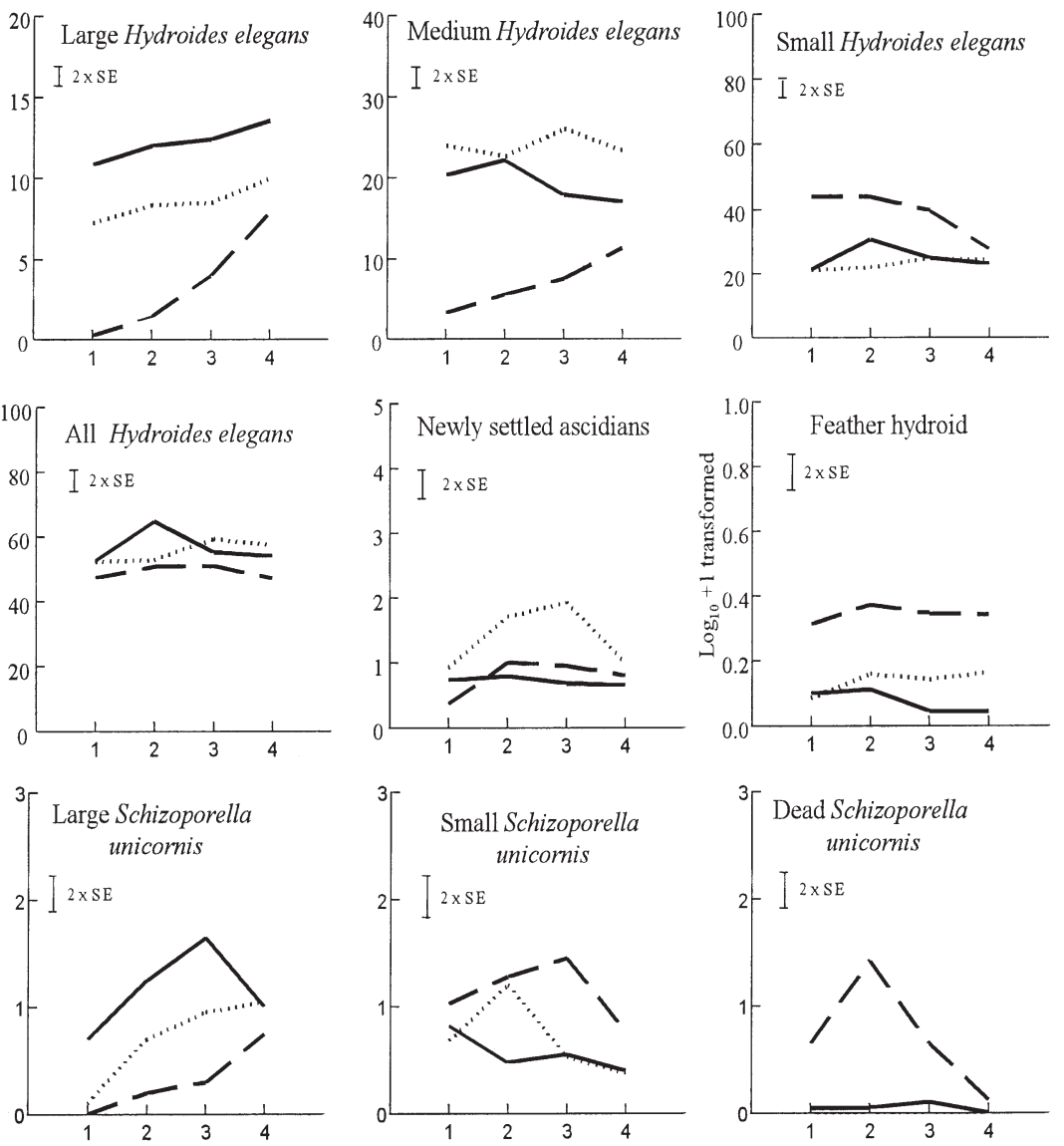

Distance from the copper source $(\mathrm{cm})$

Table 2. Probability and power values for analyses of variance of selected recruit densities in 2 wk Expts 1 and 2. Table lists overall effect of copper on density of recruits for the whole plate. Mean square terms are provided to allow reconstruction of the full ANOVA table ( $\mathrm{df}=2,12$ ) Bold: statistically significant at $\mathrm{p}<0.05$ or less

\begin{tabular}{|c|c|c|c|c|c|c|}
\hline \multirow[t]{2}{*}{ Species } & \multicolumn{3}{|c|}{ Expt 1} & \multicolumn{3}{|c|}{ Expt 2} \\
\hline & MS & $\mathrm{p}$ & $\begin{array}{c}\text { Power } \\
(\%)\end{array}$ & MS & $\mathrm{p}$ & $\begin{array}{c}\text { Power } \\
(\%)\end{array}$ \\
\hline Balanus amphitrite & 0.003 & 0.613 & 54 & 0.201 & 0.048 & \\
\hline Error & 0.006 & & & 0.057 & & \\
\hline Dead B. amphitrite & & & & 0.050 & 0.011 & \\
\hline Error & & & & 0.009 & & \\
\hline Amphipod tubes & 0.041 & ${ }^{*} 0.068$ & 50 & 0.004 & 0.137 & 49 \\
\hline Error & 0.012 & & & 0.002 & & \\
\hline Botryllinidae & 0.013 & 0.604 & 43 & 0.015 & 0.326 & 21 \\
\hline Error & 0.024 & & & 0.013 & & \\
\hline Bowerbankia imbracata & & & & 0.017 & 0.205 & 21 \\
\hline Error & & & & 0.010 & & \\
\hline Spirorbid sp. & & & & 0.044 & 0.003 & \\
\hline Error & & & & 0.006 & & \\
\hline Bivalves & & & & 0.019 & ${ }^{*} 0.111$ & 42 \\
\hline Error & & & & 0.008 & & \\
\hline
\end{tabular}

Fig. 1. Distribution of selected taxa in $2 \mathrm{wk}$ Expt 1 for Control, dose in Week 1 and dose in Week 2. Mean density of recruits $\left(\mathrm{cm}^{-2}\right)$ with distance $(\mathrm{cm})$ from the source. Error bars are derived from the plates $\times$ distance error term, which was used to compare distributions between treatments

Expt 1 (Fig. 1) and by a similar amount across the whole plate in Expt 2 (Fig. 2). When size classes were pooled and reexamined, there was no effect of copper pulses on $H$. elegans in Expt 1 (Fig. 1). There is an effect of distance by treatment in Expt 2 on all $H$. elegans but this showed no easily interpretable pattern (Fig. 2). Thus, in both experiments, copper pulses caused a shift in the size structure of $H$. elegans populations but not in the overall density of this organism.

Two hydroid species exhibited opposite responses to copper pulses. A small feather hydroid recruited in both experiments and occurred in higher densities on plates exposed to a copper pulse in Week 2 (Expt 1, Fig. 1), and in higher densities further away from the copper source on plates dosed in Week 2 (Expt 2; Fig. 2). A second hydroid (Hydroid sp. 1) recruited in high densities in Expt 2. It had a stoloniferous growth form that obscured individual recruits and was therefore counted as present or absent in each $\mathrm{cm}^{2}$. There was no significant difference in profiles across the plate for this hydroid, although there was a plate-wide reduction caused by a copper. Hydroid sp. 1 recruited into approximately $60 \%$ of squares on control plates and only $20 \%$ of squares on plates exposed to copper pulses in either Week 1 or 2 (Fig. 2).

The bryozoan Schizoporella unicornis recruited in moderate numbers in both experiments and had a relatively wide size range by the end of the fortnight. Large $S$. unicornis (10 or more zooids in a colony) occurred in highest densities on control plates in Expt 1 followed by plates exposed to a copper pulse in Week 1 and were lowest on plates exposed to a copper pulse in Week 2 (Fig. 1). In the second experiment, overall recruitment dropped by 
$50 \%$ and there were almost no large colonies on plates exposed to copper pulses in Week 2 while the control and Week 1 plates had similar densities (about $0.5 \mathrm{~cm}^{-2}$; Fig. 2). In Expt 1, small colonies ( $<10$ zooids per colony) recruited in highest densities on plates exposed to a copper pulse in Week 2 (Fig. 1). In the second experiment, there was an interaction between copper treatment and distance from the copper source. There were fairly even densities of small $S$. unicornis across the plate in control assemblages, whereas on plates exposed to copper pulses in Week 1 or 2 colonies recruited in highest densities furthest from the copper source and decreased to very low densities immediately next to the source (Fig. 2). Dead $S$. unicornis (skeletons) were also counted and in both experiments dead colonies were found almost exclusively on plates exposed to copper pulses in Week 2 (Figs 1 \& 2). The highest densities of dead colonies were located close to, but not immediately next to, the copper source. In Expt 1, there were virtually no dead colonies at the furthest distance from the copper source.
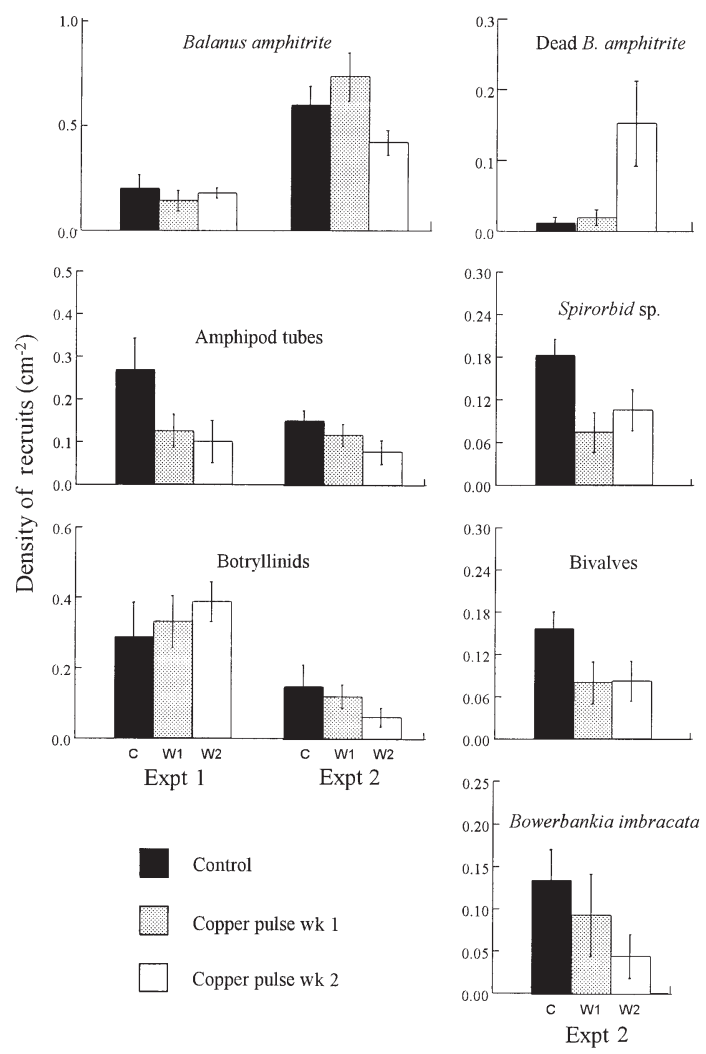

Fig. 3. Density of selected taxa in 2 wk Expts 1 and 2. Treatments are control, copper pulse in Week 1 and copper pulse in Week 2. Bars show mean density of recruits $\left(\mathrm{cm}^{-2}\right)$ plus standard error for the whole plate
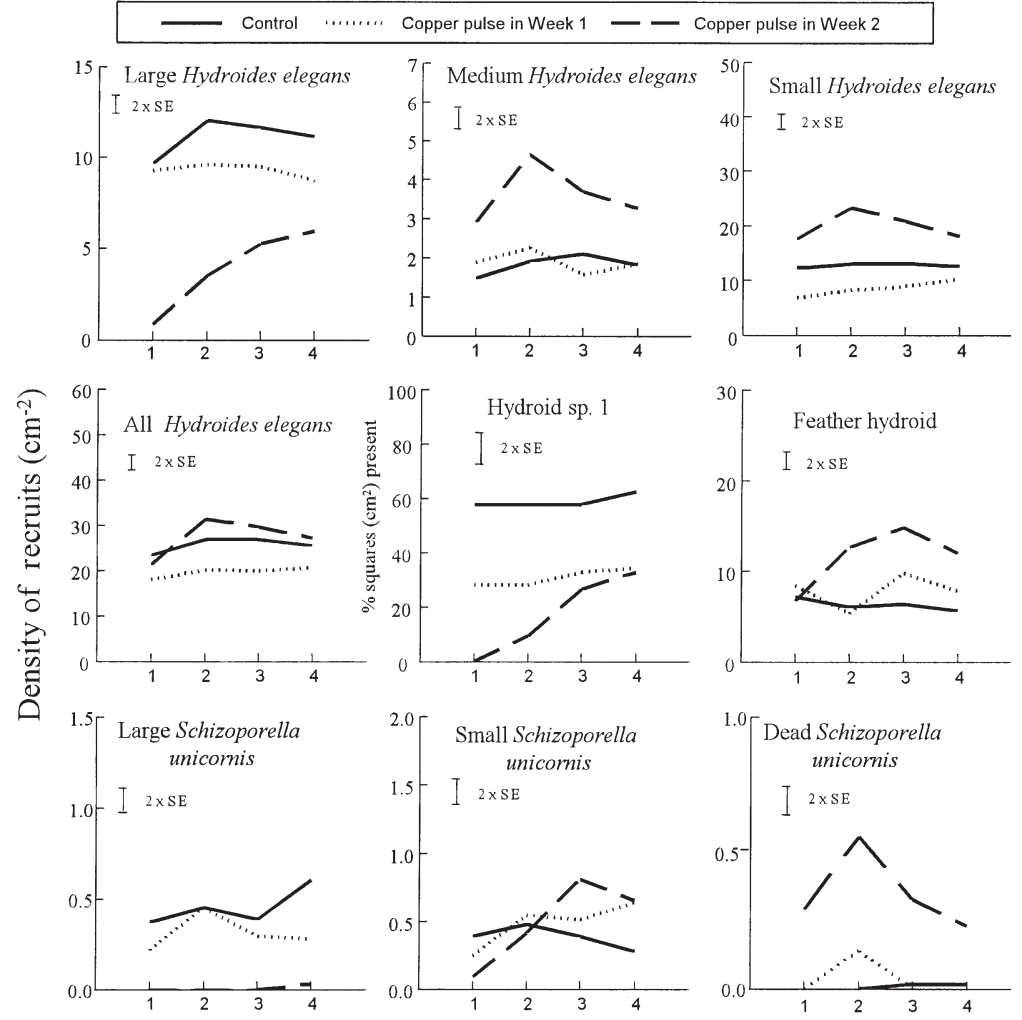

Distance from the copper source $(\mathrm{cm})$

Fig. 2. Distribution of selected taxa in 2 wk Expt 2 for Control, dose in Week 1 and dose in Week 2. Mean density of recruits $\left(\mathrm{cm}^{-2}\right)$ with distance $(\mathrm{cm})$ from the source. Error bars are derived from the plates $\times$ distance error term, which was used to compare distributions between treatments

Recruitment for the whole plate-ANOVA

Several organisms settled in relatively low densities during the short-term experiments $\left(<1 \mathrm{~cm}^{-2}\right)$ and their recruitment was analyzed for an effect of copper over the whole plate only. Mean square, probability and power values for analyses of recruit densities in both short-term experiments are summarized in Table 2 and results are graphically presented in Fig. 3. In all cases, copper pulses had either a negative effect or no impact on the densities of live recruits.

Balanus amphitrite recruited in low densities in the first experiment and power to detect differences between treatments was poor (54\%). There was no effect of copper pulses on recruit densities. Recruitment increased in the second experiment and a copper pulse in Week 2 reduced the densities of $B$. amphitrite by $20 \%$. Dead barnacles (empty tests) were also observed in this experiment and there were approximately 15 times more dead barnacles on plates exposed to a copper pulse in Week 2 than either control or Week 1 plates. Tubes of a mobile amphipod were counted and there was a reduc- 
Table 3. Analysis of effect of copper pulses on density of recruits in the 16 wk experiment, showing effects of copper on recruitment for the whole plate (Whole plate, $\mathrm{df}=4,18$ ), and on recruitment patterns with distance from the source (Within plate, $\mathrm{df}=3,12,54$ ). Mean square terms are included to allow reconstruction of the full repeated measures analysis table Bold: statistically significant at $p<0.05$ or less

\begin{tabular}{|c|c|c|c|}
\hline \multicolumn{2}{|c|}{$\begin{array}{l}\text { Taxon } \\
\quad \text { Repeated Measures Analysis }\end{array}$} & MS & $\mathrm{p}$ \\
\hline \multicolumn{4}{|c|}{ Hydroides elegans } \\
\hline Whole plate & $\begin{array}{l}\text { Treatment } \\
\text { Error }\end{array}$ & $\begin{array}{r}172.772 \\
12.702\end{array}$ & $<0.001$ \\
\hline Within plate & $\begin{array}{l}\text { Distance } \\
\text { Distance } \times \text { Treatment } \\
\text { Error }\end{array}$ & $\begin{array}{r}107.636 \\
\mathrm{t} \quad 16.075 \\
2.396\end{array}$ & $\begin{array}{l}<0.001 \\
<0.001\end{array}$ \\
\hline \multicolumn{4}{|c|}{ Solitary ascidians } \\
\hline Whole plate & $\begin{array}{l}\text { Treatment } \\
\text { Error }\end{array}$ & $\begin{array}{l}0.421 \\
0.055\end{array}$ & 0.001 \\
\hline Within plate & $\begin{array}{l}\text { Distance } \\
\text { Distance } \times \text { Treatment } \\
\text { Error }\end{array}$ & $\begin{array}{l}0.026 \\
0.042 \\
0.033\end{array}$ & $\begin{array}{l}0.510 \\
0.267\end{array}$ \\
\hline \multicolumn{4}{|c|}{ Colonial ascidians and sponges } \\
\hline Whole plate & $\begin{array}{l}\text { Treatment } \\
\text { Error }\end{array}$ & $\begin{array}{l}1.171 \\
0.175\end{array}$ & 0.002 \\
\hline Within plate & $\begin{array}{l}\text { Distance } \\
\text { Distance } \times \text { Treatment } \\
\text { Error }\end{array}$ & $\begin{array}{l}0.131 \\
0.142 \\
0.071\end{array}$ & $\begin{array}{l}0.147 \\
\mathbf{0 . 0 4 0}\end{array}$ \\
\hline \multicolumn{4}{|c|}{ All ascidians and sponges } \\
\hline Whole plate & $\begin{array}{l}\text { Treatment } \\
\text { Error }\end{array}$ & $\begin{array}{l}2.761 \\
0.138\end{array}$ & $<0.001$ \\
\hline Within plate & $\begin{array}{l}\text { Distance } \\
\text { Distance } \times \text { Treatment } \\
\text { Error }\end{array}$ & $\begin{array}{l}0.141 \\
\mathrm{t} \quad 0.234 \\
0.055\end{array}$ & $\begin{array}{r}0.065 \\
<\mathbf{0 . 0 0 1}\end{array}$ \\
\hline
\end{tabular}

and probability values for analyses of recruit densities in the longer-term (16 w) experiment are summarized in Table 3 and results are graphically presented in Fig. 4.

Hydroides elegans densities were doubled on plates exposed to copper pulses every 2 or 4 wk compared to the controls, and plates dosed every 16 or $8 \mathrm{wk}$. (2 wk $=4 \mathrm{wk}>$ Control $=16 \mathrm{wk}=8 \mathrm{wk}$, Tukey's test on main effects, $\mathrm{p}<0.05$ ). Densities of $H$. elegans decreased sharply with increasing proximity to the copper source on plates dosed most frequently ( $2 \mathrm{wk}$ ).

Solitary ascidian densities were reduced on plates dosed with copper every 2 or 4 wk compared to control or $16 \mathrm{wk}$ plates $($ Control $=16 \mathrm{wk}>2 \mathrm{wk}=4 \mathrm{wk}$, Tukey's test, $\mathrm{p}<0.05)$. The $8 \mathrm{wk}$ treatment did not differ significantly from any other treatment. A similar response was exhibited by colonial ascidians and sponges which occurred in higher densities on control and 16 wk treatments than on plates exposed to copper pulses every $2 \mathrm{wk}$ (Control = $16 \mathrm{wk}>2 \mathrm{wk}$, Tukey's test, $\mathrm{p}<0.05)$. There were no differences between other treatments. Colonial ascidians and sponges occurred in lowest densities closest to the copper source on plates dosed most frequently (2 wk) while distributions were fairly even across the plate in all other treatments. When all ascidians and sponges were analyzed together, there were lower densities of recruits on plates exposed to copper pulses at the highest frequency (every $2 \mathrm{wk}$ ) than in any other treatment. Densities of this group were also reduced on plates tion in densities of tubes on all copper dosed plates in Expt 1, but only when an outlier was removed from the data. There was no effect of copper pulses on amphipod tubes in Expt 2. There was no effect of copper pulses on botryllinid colonial ascidians in either short-term experiment, although the power to detect impacts was low. There was no effect of copper pulses on Bowerbankia imbricata (power was poor $=21 \%$ ). Copper pulses reduced the densities of a spirorbid polychaete by more than $50 \%$ in both copper treatments. The same pattern exists for newly settled bivalves but is significantly different only if an outlier is removed.

\section{Longer-term experiment}

All recruits were analyzed with distance from the copper source by repeated measures analysis. Mean square
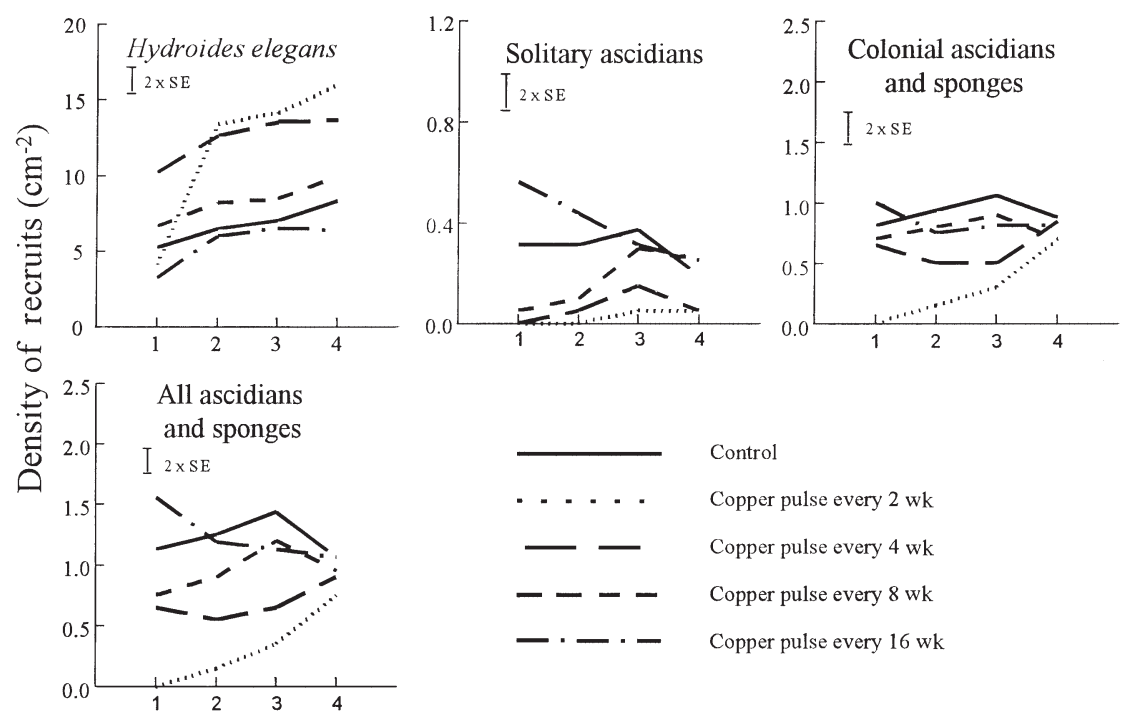

Distance from the copper source $(\mathrm{cm})$

Fig. 4. Distribution of selected taxa in the 16 wk experiment for control, and copper pulses every $2,4,8$ or $16 \mathrm{wk}$. Mean density of recruits $\left(\mathrm{cm}^{-2}\right)$ with distance $(\mathrm{cm})$ from the source. Error bars are derived from the plates $\times$ distance error term, which was used to compare distributions between treatments 
dosed every 4 wk compared to the control and $16 \mathrm{wk}$ treatments. The $8 \mathrm{wk}$ treatment did not differ from the other treatment $($ Control $=16 \mathrm{wk}>4 \mathrm{wk}>2 \mathrm{wk}$, Tukey's test, $\mathrm{p}<0.05)$. Differences between treatments were again more extreme in close proximity to the copper source.

\section{In situ measurement of copper pulse}

The temporal and spatial characterization of the copper pulses are plotted in Fig. 5. The experimental manipulation caused a large but brief increase in the concentration of dissolved copper in the water next to settlement plates. Copper concentrations measured at $24 \mathrm{~h}, 2 \mathrm{~cm}$ from the 4 copper-spiked plaster blocks ranged from 30 to $100 \mu \mathrm{g} \mathrm{l}^{-1}$. In front of control blocks, copper concentrations were indistinguishable from background and filtered blanks at $<5 \mu \mathrm{g} \mathrm{l}^{-1}$. After $3 \mathrm{~d}$ the concentrations next to copper blocks had dropped to between 10 and $50 \mu \mathrm{g} \mathrm{l}^{-1}$. At $5 \mathrm{~d}$ copper pulses were indistinguishable from background. In the experiment that measured copper with distance from the source, a clear gradient of concentration was evident from a high of $28 \mu \mathrm{g} \mathrm{l}^{-1}$ at $0.5 \mathrm{~cm}$ from the copper block to about $5 \mathrm{\mu g} \mathrm{l}^{-1}$ at $6.5 \mathrm{~cm}$ and background levels at $24 \mathrm{~cm}$. Temperatures during both experiments were 28 to $29^{\circ} \mathrm{C}$ and salinities were 29 to $30 \%$. matrix. Limitations of the sensitivity of our analyses, and the potential for contamination, mean there is little we can conclude from our measurements of the background or control copper concentrations except that they were $<5 \mu \mathrm{g}^{-1}$.

There has been extensive characterization of the existing pattern of metal contamination in Hong Kong's waters through both the use of bivalve molluscs as bio-indicators and the analysis of sediments (Phillips 1989). This has indicated relatively high levels of metal and other pollutant contamination loads in some areas of Hong Kong waters mainly Victoria and Tolo Harbours. The area of this study is Port Shelter, a large open embayment surrounded by little industrial activity and a relatively sparse population. We would estimate background concentrations in this area to be similar to coastal waters worldwide (i.e. dissolved metal concentrations of $<1 \mu \mathrm{g} \mathrm{l}^{-1}$ ).

A synthesis of available saltwater acute copper toxicity data for 57 saltwater species (Hall et al. 1998) determined a $10^{\text {th }}$ percentile value (represents a no effects concentration that would protect $90 \%$ of the test species) of $6.3 \mu \mathrm{g} \mathrm{l^{-1 }}$. The majority of species unprotected at this concentration consisted of diatoms and microalgae. It is unlikely therefore that copper concentrations on control plates (of $<5 \mu \mathrm{g} \mathrm{l}^{-1}$ ) were sufficient to cause acute toxicity to recruiting sessile invertebrates although deterrence or sublethal effects cannot be entirely ruled out.

\section{DISCUSSION}

\section{Characterization of the copper pulse}

Our experimental manipulation was successful in creating transient elevated copper concentrations that were localized next to settlement plates. The dissolved copper concentrations peaked at $24 \mathrm{~h}$ reaching concentrations of between 50 and $100 \mu \mathrm{g} \mathrm{l}^{-1}$. Concentrations remained above background levels for between 3 and $5 \mathrm{~d}$. Accurate measurement of trace level background concentrations of metals in natural waters has proven difficult due to the sensitivity limits of techniques and the ease of contamination (Florence \& Batley 1980, Crompton 1989, Apte \& Batley 1995). Although we undertook the necessary acid-washing precautions recommended for trace metal sampling (Batley et al. 1999), we did not have access to industrial-grade dust-free facilities. Moreover, we analyzed all samples diluted by a factor of 10 to reduce interference from the salt
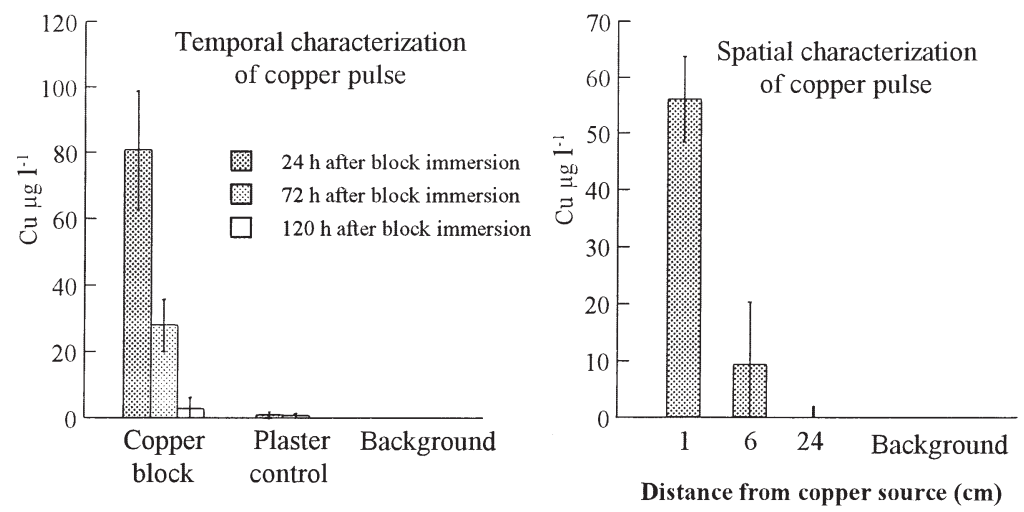

Fig. 5. Copper concentrations created by field dosing technique in $\mu \mathrm{g} \mathrm{l}^{-1}$. (a) Temporal characterization of copper pulse; samples taken $2 \mathrm{~cm}$ from the copper-spiked and control Plaster blocks 24, 72 and $120 \mathrm{~h}$ after block immersion. (b) Spatial characterization of copper pulse; samples taken $24 \mathrm{~h}$ after block immersion, 1, 6 and $24 \mathrm{~cm}$ from 4 copper-spiked plaster blocks 
Shelter. Copper was highly toxic to most settling marine invertebrates from many phyla. In this study alone, copper had negative impacts on arthropods (crustacea), bryozoans, molluscs, chordates (ascidiacea) and annelids. Where there was sufficient recruitment to analyze distributions of recruits across the plates, copper pulse impacts were generally consistent with a dose-response relationship. That is, there were far greater impacts close to the source of the toxicant where copper concentrations were highest. These patterns were particularly strong for densities of large Hydroides elegans.

In previous short-term (2 wk) experiments of identical design carried out in temperate Port Phillip Bay, Australia, few significant impacts of copper pulses have been detected (Johnston \& Keough 2000). There was abundant settlement space for the duration of these temperate experiments and it has been demonstrated that the presence of new recruits has little effect on subsequent settlement (Keough 1998). These experiments tested for the direct effects of copper pulses on independent populations of organisms (Johnston \& Keough 2000).

In Hong Kong, as in many tropical and subtropical ports, Hydroides elegans is a ubiquitous, often economically 'troublesome', fouling organism (Morton 1987, Unabia \& Hadfield 1999). We recorded high settlement rates equivalent to $>20 \mathrm{H}$. elegans per settlement plate per $\mathrm{h}$ for the duration of a short-term experiment. Growth rates were also typically fast (Qiu \& Qian 1997a, Qian \& Pechenik 1998) and in our field experiments the polychaete began limiting settlement of its own kind within a fortnight (evidenced by the reduced numbers of newly settled individuals on control plates compared to dosed ones). The impact of a pulse copper exposure was generally not detectable on the overall density (pooled across size classes) of this dominant fouling organism. Instead, the impact was dramatic in the effect it had on the size structure of the population of $H$. elegans. There were far higher densities of large $H$. elegans on control plates and far higher densities of small $H$. elegans on copper dosed plates. We were therefore able to detect an indirect positive effect of copper pulses on the densities of new recruits mediated through competition for space. In assemblages made up of fast growing, consistently high recruiting organisms, and where larval sources are widely dispersed, a localized pulse pollution event may be most easily detected as a change in the population size structure rather than a direct negative effect on overall numbers.

Serpulid polychaetes, barnacles and bryozoa all have hard skeletons that may remain attached to the substrate should the organisms inside be killed. It is clear that a copper pulse in the second week of a short- term experiment was killing settled juveniles of the barnacle Balanus amphitrite, and the encrusting bryozoan Schizoporella unicornis since skeletal remains of both these species occurred in higher densities on these plates. No Hydroides elegans skeletal remains were observed close to copper sources and this information can be used to infer that copper pulses killed or deterred serpulid larvae or new recruits rather than killing the older, more established, recruits.

\section{Longer-term experiment}

On the basis of our short-term toxicity tests we would predict a negative effect of repeated pulse copper pollution events on densities of Hydroides elegans and other sessile invertebrates. However, in our $16 \mathrm{wk}$ experiments, exposure to copper pulses had an overall positive effect on densities of $H$. elegans. In Hong Kong, dense stands of $H$. elegans dominated assemblages within 2 to 4 wk of plate immersion. Copper pulses reduced densities of these serpulids but with continued rates of high recruitment they were able to recover densities within a matter of weeks. It has been noted in other studies (e.g. Unabia \& Hadfield 1999) that although $H$. elegans is capable of rapid colonization of open surfaces it is a poor competitor for space and is often overgrown by ascidians and sponges after 2 to 3 mo (Unabia \& Hadfield 1999). In the absence of a regular pollution event on control plates in our study, colonial and solitary ascidians were able to establish, growing over and/or pushing out the small, brittle serpulids. In this way they reduced the densities of $H$. elegans. These competitive taxa were, however, reduced in densities by copper pulses and were unable to establish and grow to any great size on plates exposed to copper pulses every 2 or 4 wk.

From results of the same experiments at 2 sites in Port Phillip Bay (Johnston \& Keough in press), we also observed a positive indirect effect of copper pulses on serpulid polychaetes, caused by the reduction in densities of dominant space occupying solitary and colonial ascidians. At 1 site, the solitary ascidian Ciona intestinalis created dense monospecific stands usurping more than $90 \%$ of space on control plates within $6 \mathrm{wk}$. Copper pulses killed the ascidians and this disturbance created space for new settlers. In Hong Kong we appear to have a similar result in a very different community.

Although the effects of copper pulses on functional groups was similar at both our temperate and tropical study sites (increasing densities of serpulids and decreasing densities of ascidians), in temperate Port Phillip Bay the copper pulse acted to remove already established dominants, and in the Port Shelter copper 
pulses acted to maintain the dominance of an organism. In terms of inhibition models of assemblage development (Connell \& Slatyer 1977, Greene et al. 1983), disturbance was necessary in Port Phillip Bay to cause the removal of a good competitor and allow 'early successional' species to succeed, while in Hong Kong disturbance prevented good competitors from ever becoming established and maintained dominance of an 'early successional' species.

Assemblage dynamics may differ between climates and it has been contested that tropical assemblages of fouling organisms will have higher recruitment and growth rates (Schoener et al. 1978). When examining the frequency of a disturbance, it is therefore of interest to contrast sites within the same climate but also in vastly different climates where the rate of assemblage 'recovery' from a disturbance may be predicted to be faster. The speed of recovery of assemblages in the Hong Kong short-term experiments was rapid as evidenced by the differences between the impact of a pulse exposure in Week 1 and Week 2. In many cases, a pulse exposure in Week 1 had an intermediate effect or no effect compared to the differences between control and a copper pulse in Week 2. Older assemblages in Hong Kong recovered more quickly from copper pulse pollution events than similar assemblages in Port Phillip Bay, where the impact of a single copper pulse on an 8 wk old assemblage was still evident after a further $8 \mathrm{wk}$ (Johnston \& Keough in press). Far greater levels of experiment repetition through space and time would be necessary, however, before it would be possible to forge generalizations regarding the recovery of tropical versus temperate ecosystems from pulse pollution events.

Field toxicity tests allow the examination of indirect effects of toxicants not possible in single species toxicity tests (DeAngelis 1996). Space has been consistently identified as a primary limiting resource in marine hard-substrate communities (Connell 1961, Dayton 1971, Jackson 1977, Osman 1977, Kay \& Keough 1981) and many complicating factors have been identified that can act to minimize the predictability of competitive processes for space such as; recruitment histories, disturbance and predation (Connell \& Slatyer 1977, Osman 1977, Sousa 1980, Greene et al. 1983, BenedettiCecchi et al. 1999). This study demonstrates that anthropogenic disturbances can interact with competitive processes and that field tests are a useful tool with which to investigate the resultant indirect effects.

Acknowledgements. We are grateful to many people for field and laboratory assistance but especially to Lisa Soo, Jian-Wen Qiu and Tania Ng. We thank Liz Morris for helpful discussion and criticism of the original manuscript. Emma Johnston was supported throughout this study by an Australian Postgradu- ate Award (APA), and travel to Hong Kong was made possible through a University of Melbourne International Travel Scholarship, the Department of Zoology Drummond Award and the Daniel Curdie Science Prize.

\section{LITERATURE CITED}

Apte SC, Batley GE (1995) Trace metal speciation of labile chemical species in natural waters and sediments: nonelectrochemical approaches. In: Tessier A, Turner DR (eds) Metal speciation and bioavailability in aquatic systems, Vol 3. John Wiley \& Sons Ltd., Chichester, p 259-306

Batley GE, Apte SC, Stauber JL (1999) Acceptability of aquatic toxicity-data for the derivation of water quality guidelines for metals. Mar Freshw Res 50:729-738

Benedetti-Cecchi L, Menconi M, Cinelli F (1999) Pre-emption of the substratum and the maintenance of spatial pattern on a rocky shore in the northwest Mediterranean. Mar Ecol Prog Ser 181:13-23

Bryan GW (1971) The effects of heavy metals (other than mercury) on marine and estuarine organisms. Proc R Soc Lond Ser B 177:389-410

Bryan PJ, Kreider JL, Qian PY (1998) Settlement of the serpulid polychaete Hydroides elegans (Haswell) on the arborescent bryozoan Bugula neritina (L.): evidence of a chemically mediated relationship. J Exp Mar Biol Ecol 220:171-190

Calow P (1994) Handbook of ecotoxicology, 1st edn. Blackwell Scientific Publications, Oxford

Campbell PG (1995) Interaction between trace metals and aquatic organisms: a critique of the free ion activity model. In: Tessier A, Turner DR (eds) Metal speciation and bioavailability in aquatic systems. John Wiley \& Sons Ltd., Chichester, p 45-102

Connell JH (1961) The influence of interspecific competition and other factors on the distribution of the barnacle Chthamalus stellatus. Ecology 42:710-723

Connell JH (1978) Diversity in tropical rain forests and coral reefs. Science 199:1302-1310

Connell JH, Slatyer RO (1977) Mechanisms of succession in natural communities and their role in community stability and organisation. Am Nat 111:1119-1144

Crompton TR (1989) Analysis of seawater. Butterworths, London

Dayton PK (1971) Competition, disturbance and community organisation: the provision and utilisation of space in a rocky intertidal community. Ecol Monogr 41:351-389

DeAngelis DL (1996) Indirect effects: concepts and approaches from ecological theory. In: Baird DJ, Maltby L, Greig-Smith P, Douben P (eds) ECOtoxicology: ecological dimensions. Chapman \& Hall, London, p 25-41

Florence TM, Batley GE (1980) Chemical speciation in natural waters. In: CRC critical reviews in analytical chemistry. CRC Press, Boca Raton, p 219-296

Gaines S, Roughgarden J (1985) Larval settlement rate: a leading determinant of structure in an ecological community of the marine intertidal zone. Proc Natl Acad Sci USA 82:3707-3711

Gosselin LA, Qian PY (1997) Can bacterivory alone sustain larval development in the polychaete Hydroides elegans and the barnacle Balanus amphitrite? Mar Ecol Prog Ser 161:93-101

Greene CH, Schoener A, Corets E (1983) Succession on marine hard substrata: the adaptive significance of solitary and colonial strategies in temperate fouling communities. Mar Ecol Prog Ser 13:121-129 
Hall LWJ, Scott MC, Killen WD (1998) Ecological risk assessment of copper and cadmium in surface waters of Chesapeake Bay Watershed. Environ Toxicol Chem 17: $1172-1189$

Hughes T, Connell JH (1999) Multiple stressors on coral reefs: a long-term perspective. Limnol Oceanogr 44:932-940

Jackson J (1977) Competition on marine hard substrata: the adaptive significance of solitary and colonial strategies. Am Nat 111:743-767

Johnston EL, Keough MJ (2000) Field assessment of the effects of the timing and frequency of copper pulses on settlement of sessile marine invertebrates. Mar Biol 137: $1017-1029$

Johnston EL, Keough MJ (in press) Direct and indirect effects of repeated pulse disturbances from copper on the development of marine invertebrate assemblages. Ecol Appl

Johnston EL, Webb JA (2000) Novel techniques for field assessment of copper toxicity on fouling assemblages. Biofouling 15:165-173

Kay AM, Keough MJ (1981) Occupation of patches in the epifaunal communities on pier pilings and the bivalve Pinna bicolor at Edithburgh, South Australia. Oecologia 48:123-130

Keough MJ (1998) Responses of settling invertebrate larvae to the presence of established recruits. J Exp Mar Biol Ecol 231:1-19

Keough MJ, Quinn GP (1998) Effects of periodic disturbances from trampling on rocky intertidal algal beds. Ecol Appl 8: 141-161

Kimball KD, Levin SA (1985) Limitations of laboratory bioassays: The need for more ecosystem level testing. Bioscience 35:165-171

Levine SN (1989) Theoretical and methodological reasons for variability in the response of aquatic ecosystem processes to chemical stress. In: Levin SA, Harwell MA, Kelly JR, Kimball KD, Reichle DE (eds) Ecotoxicology: problems and approaches. Springer Verlag, New York, p 149-179

Lewis AG, Cave WR (1982) The biological importance of copper in oceans and estuaries. Oceanogr Mar Biol Annu Rev 20:471-695

Luoma SN (1995) Prediction of metal toxicity in nature from bioassays: limitations and research needs. In: Tessier A, Turner DR (eds) Metal speciation and bioavailability in aquatic systems, Vol 3. John Wiley \& Sons, Chichester, p 609-646

Menge BA, Sutherland JP (1987) Community regulation: vari-

Editorial responsibility: Otto Kinne (Editor),

Oldendorf/Luhe, Germany ation in disturbance, competition, and predation in relation to environmental stress and recruitment. Am Nat 130: $730-757$

Morton B (1987) Recent marine introductions into Hong Kong. Bull Mar Sci 41:503-513

Osman R (1977) The establishment and development of a marine epifaunal community. Ecol Mon 47:37-63

Paine RT, Levin SA (1981) Intertidal landscapes: disturbance and the dynamics of pattern. Ecol Monogr 51:145-178

Pechenik JA (1987) Environmental influences on larval survival and growth. In: Giese A, Pearse J, Pechenik JA (eds) Reproduction of marine invertebrates, Vol 9. Blackwell Scientific Publications, New York, p 551-608

Phillips DJH (1989) Trace metals and organochlorines in the coastal waters of Hong Kong. Mar Poll Bull 20:319-327

Qian PY, Pechenik JA (1998) Effects of larval starvation and delayed metamorphosis on juvenile survival and growth of the tube-dwelling polychaete Hydroides elegans (Haswell). J Exp Mar Biol Ecol 227:169-185

Qiu JW, Qian PY (1997a) Combined effects of salinity, temperature and food on early development of the polychaete Hydroides elegans. Mar Ecol Prog Ser 152:79-88

Qiu JW, Qian PY (1997b) Effects of food availability, larval source and culture method on larval development of Balanus amphitrite amphitrite Darwin: implications for experimental design. J Exp Mar Biol Ecol 217:47-61

Qiu JW, Qian PY (1998) Combined effects of salinity and temperature on juvenile survival, growth and maturation in the polychaete Hydroides elegans. Mar Ecol Prog Ser 168: 127-134

Qiu JW, Gosselin LA, Qian PY (1997) Effects of short-term variation in food availability on larval development in the barnacle Balanus amphitrite amphitrite. Mar Ecol Prog Ser 161:83-91

Schoener A, Long E, DePalma J (1978) Geographic variation in artificial island colonisation curves. Ecology 59:367-382

Schratzberger M, Warwick RM (1998) Effects of the intensity and frequency of organic enrichment on two estuarine nematode communities. Mar Ecol Prog Ser 164:83-94

Sousa WP (1980) The responses of a community to disturbance: the importance of successional age and species' life histories. Oecologia 45:72-81

Unabia C, Hadfield MG (1999) Role of bacteria in larval settlement and metamorphosis of the polychaete Hydroides elegans. Mar Biol 133:55-64

Submitted: January 11, 2001; Accepted: June 12, 2001

Proofs received from author(s): January 8, 2002 